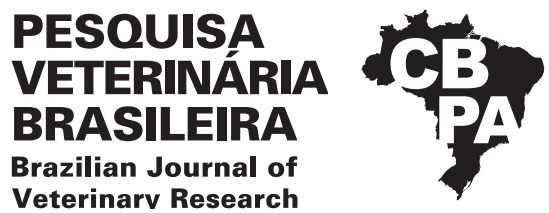

Pesq. Vet. Bras. 41:e06650, 2021

DOI: $10.1590 / 1678-5150-P V B-6650$

Original Article

Small Animal Diseases

ISSN 0100-736X (Print)

(cc) BY-NC

ISSN 1678-5150 (Online)

\title{
Gestational echobiometry in brachycephalic bitches using high-definition ultrasonography ${ }^{1}$
}

\author{
Marjury C. Maronezi ${ }^{2}$, Ana Paula R. Simões ${ }^{2}$, Ricardo A.R. Uscategui ${ }^{3}$, \\ Letícia Pavan², Mariana G.K. Rodrigues², Renata S.G. Mariano ${ }^{2}$, \\ Victor J.C. Santos ${ }^{2}$ and Marcus A.R. Feliciano ${ }^{2,4 *}$ (D)
}

\begin{abstract}
Maronezi M.C., Simões A.P.S., Uscategui R.A.R., Pavan L., Rodrigues M.G.K., Mariano R.S.G., Santos V.J.C. \& Feliciano M.A.R. 2021. Gestational echobiometry in brachycephalic bitches using high-definition ultrasonography. Pesquisa Veterinária Brasileira 41:e06650, 2021. Departmento de Clínica e Cirurgia Veterinária, Faculdade de Ciências Agrárias e Veterinárias, Universidade Estadual Paulista "Júlio de Mesquita Filho", Via de acesso Prof. Paulo Donato Castellane s/n, Jaboticabal, São Paulo, SP 14884-900, Brazil. E-mail: marcusfeliciano@yahoo.com.br

The objective of the present study was to obtain echobiometric values for the most important canine maternal-fetal tissues using high-definition ultrasonography (HDUS) trying to update the formulas for predicting gestational age. Twelve healthy bitches of brachycephalic breeds weighing $7-13 \mathrm{~kg}$ and aged one to four years were included. The fetuses were analyzed every day using conventional and high-definition ultrasonography from the eighth day after artificial insemination until the day of delivery, using the ACUSON S2000/SIEMENS ultrasound equipment and specific software. Embryonic and fetal structures; diameter of the embryonic vesicle; length of the embryo; biparietal diameter, abdominal length and kidney height; length of the femur, humerus, scapula, radius, and tibia; thickening of the stomach wall; adrenal length; and cardiac size were measured. These variables were correlated with gestational and adjusted tested according to regression models. The results obtained $(P<0.001)$ for: lateral diameter of the gestational sac $(\mathrm{R} 2=81.8 \%)$; length of the embryo (R2=85.7\%); biparietal $(\mathrm{R} 2=99.1 \%)$ and abdominal diameter $(\mathrm{R} 2=97.2 \%)$; thickness of the gastric wall ( $\mathrm{R} 2=86.9 \%)$; length of the femur ( $\mathrm{R} 2=96.6 \%)$, radius ( $\mathrm{R} 2=97.5 \%)$, humerus ( $\mathrm{R} 2=96.5 \%)$, scapula (R2=95.8\%) and tibia (R2=97.3\%); kidney length (R2=95.8\%) and height (R2=96.0\%); adrenal length $(\mathrm{R} 2=89.6 \%)$; heart length $(\mathrm{R} 2=93.0 \%)$ and height $(\mathrm{R} 2=91.5 \%)$ of the canine fetuses showed significant correlation with gestational days. This allowed monitoring fetal growth and estimation of age with high accuracy in different gestational periods.
\end{abstract}

INDEX TERMS: Echobiometry, brachycephaly, bitches, ultrasonography, dogs, pregnancy.

RESUMO.- [Ecobiometria gestacional em cadelas braquicefálicas utilizando ultrassonografia de altadefinição.] 0 objetivo do presente estudo foi obter valores ecobiométricos para os tecidos materno-fetais caninos, usando

\footnotetext{
${ }^{1}$ Received on June 3, 2020.

Accepted for publication on July 15, 2020.

${ }^{2}$ Departamento de Clínica e Cirurgia Veterinária, Faculdade de Ciências Agrárias e Veterinárias (FCAV), Universidade Estadual Paulista "Júlio de Mesquita Filho" (Unesp), Via de acesso Prof. Paulo Donato Castellane s/n, Jaboticabal, São Paulo, SP 14884-900, Brazil.

${ }^{3}$ Universidade Federal dos Vales do Jequitinhonha e Mucuri (UFVJM), Avenida Universitária 1000, Unaí, MG 38610-000, Brazil.

${ }^{4}$ Departamento de Clínica de Grandes Animais, Universidade Federal de Santa Maria (UFSM), Av. Roraima 1000, Camobi, Santa Maria, RS 97105-900, Brazil. *Correspondent author: marcusfeliciano@yahoo.com.br
}

a ultrassonografia de alta definição (HDUS), desenvolvendo fórmulas para prever a idade gestacional das cadelas. Doze cadelas saudáveis de raças braquicefálicas pesando 7-13kg e com idades entre um e quatro anos foram incluídas. Os fetos foram analisados diariamente com ultrassonografia convencional e de alta definição, do oitavo dia após a inseminação artificial até o dia do parto, utilizando o equipamento de ultrassom ACUSON S2000/SIEMENS e software específico. Estruturas embrionárias e fetais; diâmetro da vesícula embrionária; comprimento do embrião; diâmetro biparietal, comprimento abdominal e altura renal; comprimento do fêmur, úmero, escápula, rádio e tíbia; espessamento da parede do estômago; comprimento adrenal; e tamanho cardíaco foram medidos. Essas variáveis foram correlacionadas com o teste gestacional e ajustado de acordo com os modelos de regressão. Os 
resultados obtidos $(P<0,001)$ para: diâmetro lateral do saco gestacional (R2=81,8\%); comprimento do embrião (R2=85,7\%); diâmetro biparietal (R2=99,1\%) e abdominal (R2=97,2\%); espessura da parede gástrica (R2=86,9\%); comprimento do fêmur (R2=96,6\%), rádio (R2=97,5\%), úmero (R2=96,5\%), escápula (R2=95,8\%) e tíbia (R2=97,3\%); comprimento do rim (R2=95,8\%) e altura (R2=96,0\%); comprimento adrenal (R2=89,6\%); o comprimento do coração (R2=93,0\%) e a altura (R2=91,5\%) dos fetos caninos apresentaram correlação significativa com os dias gestacionais. Isso permitiu monitorar o crescimento fetal e estimar a idade com alta precisão em diferentes períodos gestacionais.

TERMOS DE INDEXAÇÃO: Ecobiometria, gestação, cadelas, braquicefalia, ultrassonografia, caninos.

\section{INTRODUCTION}

C Gestational ultrasonography has great utility in routine obstetric examination of small animals, since it is the most accurate diagnostic method to evaluate pregnancy and is harmless to both the mother and the fetus (Nepomuceno et al. 2013). This technique enables monitoring organ development, determining viability and estimation of gestational age by echobiometry of maternal, embryonic, and fetal structures (Lopate 2008).

Echobiometry is an important tool to analyze gestational structures, morphometrically evaluate development of the fetus and predict gestational age and the probable date of delivery (Miranda \& Domingues 2010). This technique evaluates development of fetal growth during pregnancy and is important to reduce prenatal mortality as it contributes to diagnosis of disorders that may negatively affect pregnancy (Johnsen et al. 2008).

In human obstetrics, new ultrasonographic techniques have been proposed with the objective of increasing the accuracy of gestational monitoring. High-definition ultrasonography (HDUS) is a technique that is known to generate images of high quality (Bonilla-Musoles et al. 2013, Nawapun et al. 2018). However, this technique has not been described in veterinary medicine to evaluate pregnancy in canines.

Considering the significance of echobiometry and the remarkable applicability in pregnant women, the HDUS technique can enable early detection of maternal and fetal structures. In addition, the accurate use of canine fetal echobiometry can provide new ultrasonographic measurements and parameters for the study and estimation of gestational age in dogs. Following these precepts, the objective of the present study was to evaluate the efficiency of high definition ultrasonographic examination to predict gestational age in brachycephalic bitches by determining echobiometric parameters and monitoring the development of maternal embryonic and fetal tissues.

\section{MATERIALS AND METHODS}

This study was approved by the institutional Animal Ethics Committee (3652/17). It included 12 females ( 1 to 4 years old, weighing 7 to $13 \mathrm{~kg}$ ) of the following breeds: French Bulldog (n=8); Pug ( $n=2)$; and Shih-tzu $(n=2)$. All dogs were healthy based on physical examination, complete blood count, biochemical profile, and ultrasonographic examination of the reproductive tract. The dogs were from regional kennels that have a partnership with the department. The owners of the dogs provided informed written consent for participation of their animals in the study.

All bitches were conditioned for, approximately 30 days before insemination according to reproductive records of the animals assigned by tutors, simulated ultrasonographic examination every day and the hair of abdominal region clipped. The kennel owners were trained to detect the first signs of proestrus and to decide the best time for artificial insemination. After oestrous confirmation by vaginal cytology, all animals underwent intrauterine artificial insemination (AI) with fresh semen every $24 \mathrm{~h}$ for three consecutive days (Jacomini et al. 2006). The selected males (same breed as the receiving bitches) were considered to be suitable for reproduction after clinical and urological examination. Eight days after the last artificial insemination, the dogs were housed in individual kennels with appropriate bedding and controlled ventilation, light, and temperature. They were fed a commercial diet for pregnant dogs and had ad libitum access to water until delivery.

Ultrasonography was performed using the ACUSON S2000 ${ }^{\text {TM }}$ equipment (Siemens, Munich, Germany) and a high resolution (18L6HD) digital transducer with a standard frequency of $17.0 \mathrm{MHz}$. Gain, focus and other parameters were adjusted during initial examination to obtain the best image for each fetus evaluated. Daily from the eighth day after the last insemination until delivery, the animals were transferred to the ultrasonography laboratory and placed in left dorsolateral decumbency position. Ultrasound gel was used to optimize image acquisition. An experienced technician performed all the ultrasonography examinations.

For the analyses the last artificial insemination was considered as day zero and gestational time was calculated retrospectively from the delivery date considering a normal period of 57 to 63 days due to the variable proestrus and estrus cycles in dogs (Concannon et al. 1989). During the ultrasonography evaluation, gestational age was estimated in days, based on the recommendations of Feliciano et al. (2015) and Mattoon \& Nyland (2015), combined with the evaluation of intestinal and kidney development as reported by Gil et al. $(2015,2018)$. The ultrasonography protocol described by Gil et al. (2014) was followed to evaluate the highest number of fetuses in each pregnant bitch.

Ultrasonic examinations were performed on longitudinal and transverse sections to identify the uterus, and embryonic or fetal structures (the gestational vesicle, embryo, abdomen, head, scapula, humerus, radius, femur, tibia, metatarsus, kidneys, heart, stomach and adrenal). HDUS findings were divided into two phases according to gestational development: embryonic (from first to gestational 35th day) and fetal (from 35th gestational day until delivery) (Pretzer 2008).

After identification of the embryonic or fetal structures using HDUS, measurements were performed: external dorsoventral (EDV) and latero-lateral (ELL) diameter of the embryonic vesicle; internal dorsoventral (IDV) and latero-lateral (ILL) diameter of the embryonic vesicle; embryo length (EL); biparietal (BPD) and abdominal (AD) diameter; femur (FEM), humerus (HUM), scapula (ESC) radius (RAD), and tibia (TIB) length; kidney length (KL) and height $(\mathrm{KH})$; adrenal gland length (AGL); stomach wall thickness (STO). HR in beats/min was obtained by means of pulsed Doppler ultrasonography. In addition, measurements were made of the heart length from the base to apex (HL) and the heart width of the left to right wall in the region closest to the base $(\mathrm{HH})$.

The R-project ${ }^{\mathrm{TM}}$ software (Foundation for statistical computing, Austria) was used for the statistical analyses. Parameter distribution (Shapiro-Wilk test) and homoscedasticity (Bartlett's test) were 
initially tested. Subsequently, real or transformed measurements were correlated with gestational days using the Spearman's test. When significant, parameters and gestational age were adjusted and tested according to regression models (linear, quadratic and cubic). Significance level was set at $5 \%$ for all tests and the results were presented as mean \pm SD (standard deviation).

\section{RESULTS}

The mean gestational period for the 12 bitches was $61 \pm 3$ days (minimum 59 and maximum 63 days) and 68 fetuses were evaluated. All pups were born healthy and the mean number of pups per litter was $5 \pm 3$.

Pregnancy was confirmed on the 10th gestational day, according to the detection of gestational sacs and structures. The echobiometry of gestational sacs (EGS) was performed from the 10 th to the 23 rd gestational days. The structure was identified as a rounded anechoic cavity with fine and hyperechoic contours, measuring $0.7-1.7 \mathrm{~mm}$ in internal diameter when first detected. The size of the anechoic cavity increased up to the 23rd day, measuring 5.9-8.9mm (IDV) (Fig.1A).
The first visualization of an embryonic structure occurred on the 17 th gestational day (day 17 to 18 ). Embryonic length was measured from the first day of detection until the 30th gestational day, which showed gradual growth and doubling in size every three days (Fig.1B). On the 21st gestational day, heartbeat was evident in all embryos; however, was also detected on the 18th day in some cases. On the first day of detection, low frequency (minimum 121 and maximum 139 bpm) of heart rate was observed, which stabilized between 200 and $240 \mathrm{bpm}$ after four days.

On the 25th gestational day, measurement of biparietal diameter (Fig.2A) was initiated and it was possible to identify the structure and measure the length of the kidney in some fetuses (Fig.3A). The tibia, radius, and scapula were identified and measured from day 38 (Fig.4). On the 30th gestational day, measurement of the diameter of the abdomen (Fig.2B), thickness of the stomach wall and femoral length was possible (Fig.5A and 6A). Measurement of the height of the heart and kidney was initiated on day 31 (Fig.3A and 6B). At this gestational age, the adrenal gland was also detected in most of the fetuses and the longitudinal length was measured (Fig.3B).

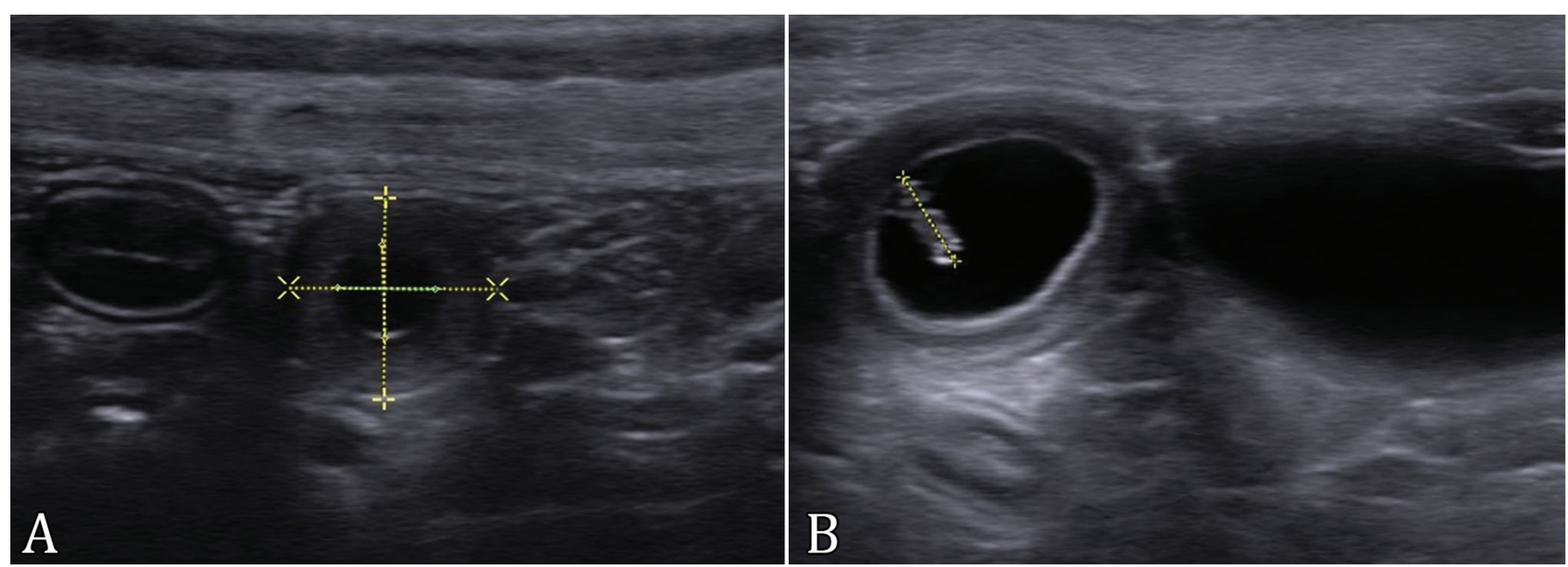

Fig.1. Ultrasonographic image of embryonic echobiometry of brachycephalic dogs. Echobiometry of the (A) gestational sac (between cursors) and (B) length of the embryo (between cursors).
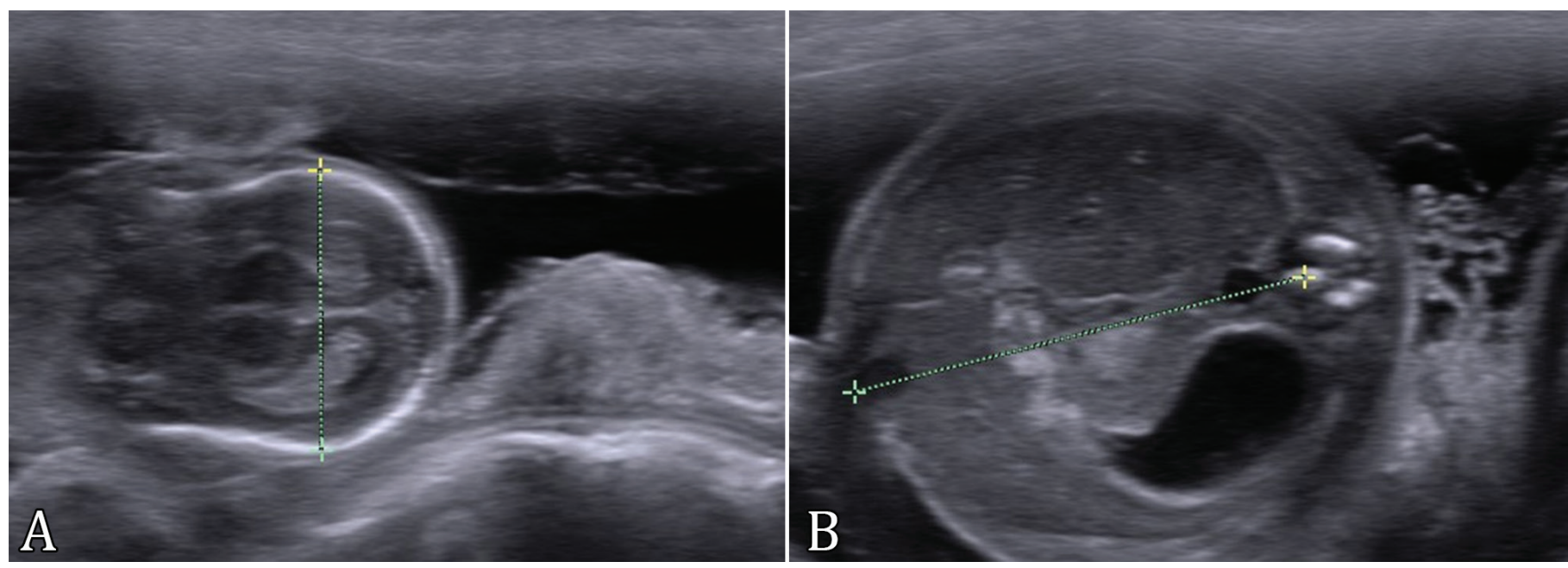

Fig.2. (A) Biparietal diameter (between cursors) and (B) abdominal diameter (between cursors). 
Biometry was performed without any difficulty; however obtaining satisfactory images two days prior to delivery was challenging due to the size of the litter. Results of the regression study of the echobiometric parameters that showed a significant correlation with gestational age are described in Table 1. Figure 7 shows the graphical representation of the three parameters with the highest coefficient of determination for embryonic and fetal gestational age estimation.

\section{DISCUSSION}

All embryonic and fetal ultrasonographic parameters measured in the present study showed significant correlation with gestational days, enabling estimation of gestational age with variable accuracy, in addition to monitoring fetal growth. To the best of our knowledge, this is the first echobiometric study of daily evaluation of pregnant brachycephalic bitches using HDUS as an imaging method, with some structures being evaluated for the first time in the veterinary literature.

Weekly echobiometry in brachycephalic bitches can aid in the evaluation of fetal development and estimation of gestational age (Feliciano et al. 2015). However, the weekly biometry of canine fetuses shows variations that estimate an early delivery date (Teixeira et al. 2009). In this context, the daily echobiometry performed in the present study enables more precise calculation of gestational age and an adequate evaluation of the mother and fetuses. Additional, assist in the diagnosis early of gestational alterations that may compromise this physiological process in bitches and provide more tools for obstetricians to plan gestational care (Feliciano et al. 2008).

The gestational sac could be evaluated on the 10 th gestational day, which has not been possible previously. This fact can be justified by embryogenesis (Monteiro et al. 2011). Among the parameters evaluated, measurement of the ELL presented the best correlation with gestational age $\left(\mathrm{R}^{2}=82 \%\right)$ during the embryonic phase, in contrast to that reported in a study by (Feliciano et al. 2013), who observed better correlation $\left(\mathrm{R}^{2}=70 \%\right)$ by weekly evaluation of the ILL. The present study obtained daily data, providing more accurate formulas of gestational age. The diameter of the gestational sac also may be different in abnormal pregnancies, and an early diagnosis is important to identify abnormalities (Freitas et al. 2016).

The embryo was measured from the 17 th to the 30 th gestational days, a period that monitors the moment of implantation until the embryo becomes a fetus (Phemister 1974). Contrary to the observations of the present study, Pretzer (2008) reported that embryos are first seen in B-mode between the 22nd and 23rd days. However, as noted in this experiment, studies based on canine embryology report that at day 21 the embryo is $4.5 \mathrm{~mm}$ long (Pieri et al. 2015). Monitoring embryonic development is necessary since death of one or more embryos may not cause clinical signs (Sharma et al. 2018).
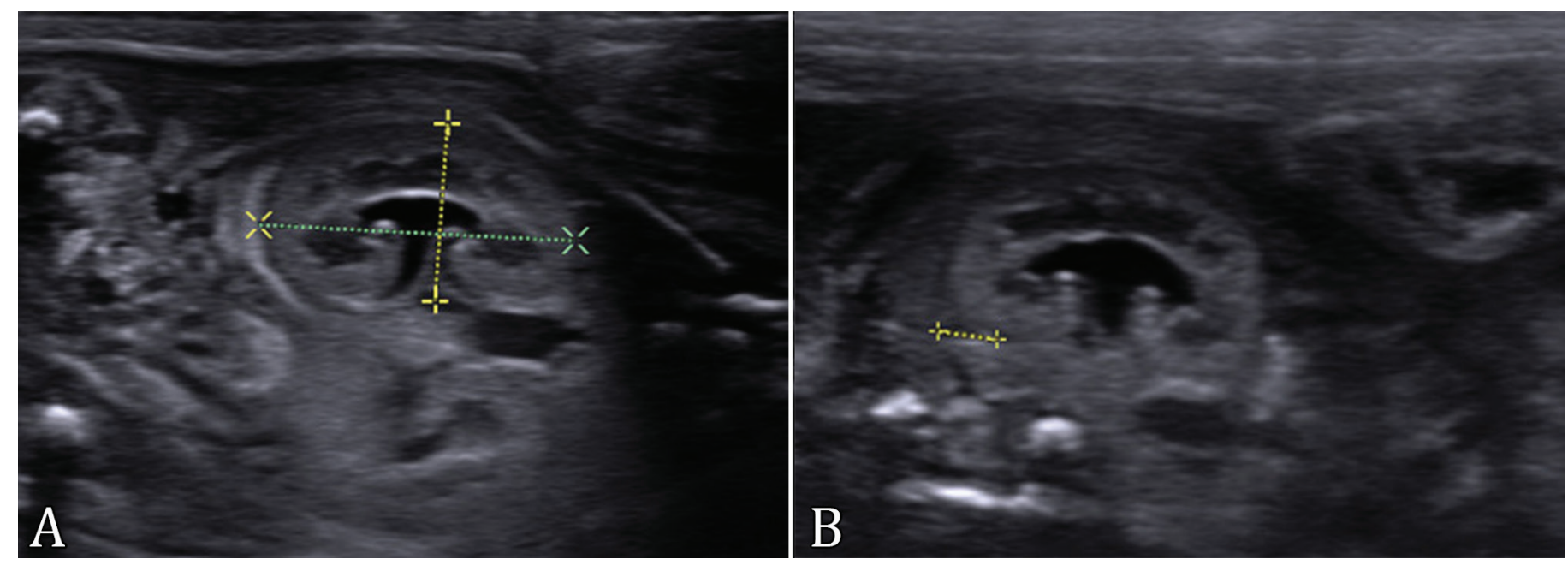

Fig.3. (A) Kidney length and height (between cursors) and (B) adrenal length (between cursors).
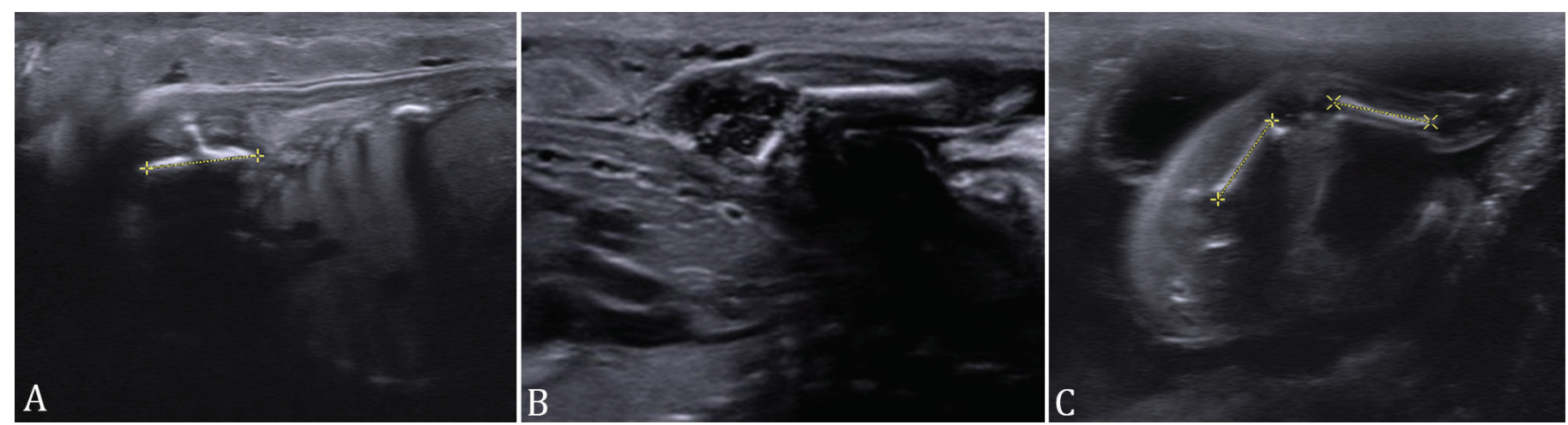

Fig.4. (A) Length of scapula (between cursors), (B) length of the radio (arrow) and (C) length of the tibia (arrow). 
The present study showed kidney echobiometry as a discrete predictor of gestational age, corroborating human studies that demonstrate the usefulness of measurement of the length of the kidney to evaluate fetal abnormalities; however, not as a good indicator of growth (Brennan et al. 2017). In human the of renal biometry is utilize as an additional method for estimation of fetal age and to identify congenital kidney diseases (Dias et al. 2014). This parameter contradicts that reported by Feliciano et al. (2014), who suggested kidney echobiometry as an appropriate predictor of gestational age in bitches.

Biparietal diameter was the best predictor of gestational age in the present study for fetal phase, corroborating other studies (Mattoon \& Nyland 2015, Teixeira et al. 2009). Moreover, BPD presented the best coefficient of determination $\left(\mathrm{R}^{2}=99 \%\right)$ providing gestational age formula with excellent prediction and can be evaluated from the 25th gestational day until the day of delivery, which is in contrast to that described in the literature (Jabin et al. 2007) that indicates the usefulness of this parameter only after the 30th gestational day (Feliciano et al. 2007, Teixeira et al. 2009).
Biometry of the layers of the stomach is known in humans and sheep, where the values have a linear correlation with gestational age (David et al. 2010), as in the results of the present study. Measurement of the gastric wall was facilitated after day 27, a fact never reported in canine fetuses. This parameter has great clinical relevance in humans as it relates to prenatal genetic therapies for gastrointestinal diseases (Abi-Nader et al. 2009) and can provide subsidies for future studies in small animals.

Abdominal diameter can be measured from the fifth gestational week in brachycephalic bitches and presents a linear increase and good correlation with gestational age (Camargo et al. 2011, Feliciano et al. 2015). This observation corroborates the present study; however, our results showed superior coefficient of determination $\left(\mathrm{R}^{2}=97 \%\right)$ to that reported in the abovementioned studies. The evaluation of abdominal diameter can be useful in abnormalities such as: congenital abdominal wall defects and hydrops, where in which the abdominal diameter is larger than that of normal fetuses (Freitas et al. 2016).

The length of the femur in human fetus is considered an excellent predictor of gestational age in the second trimester

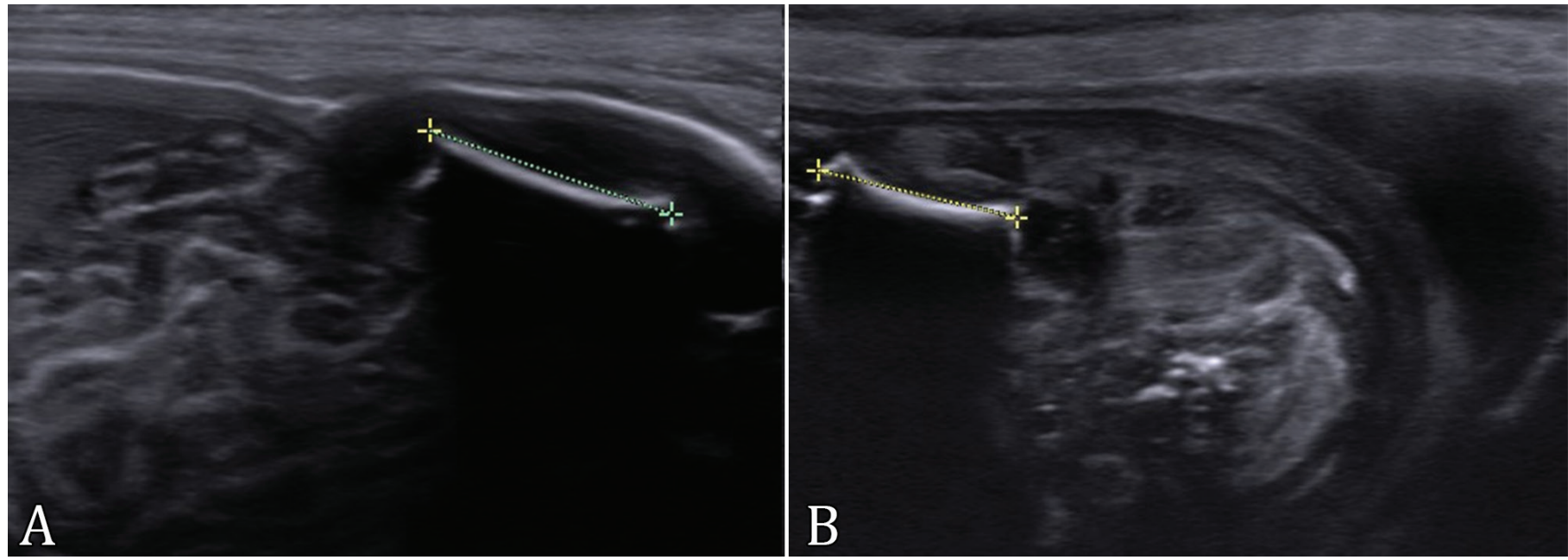

Fig.5. Ultrasonographic image of the ecobiometry in canine braquicephalic concepts, (A) femur length (arrow) and (B) humerus length (arrow).

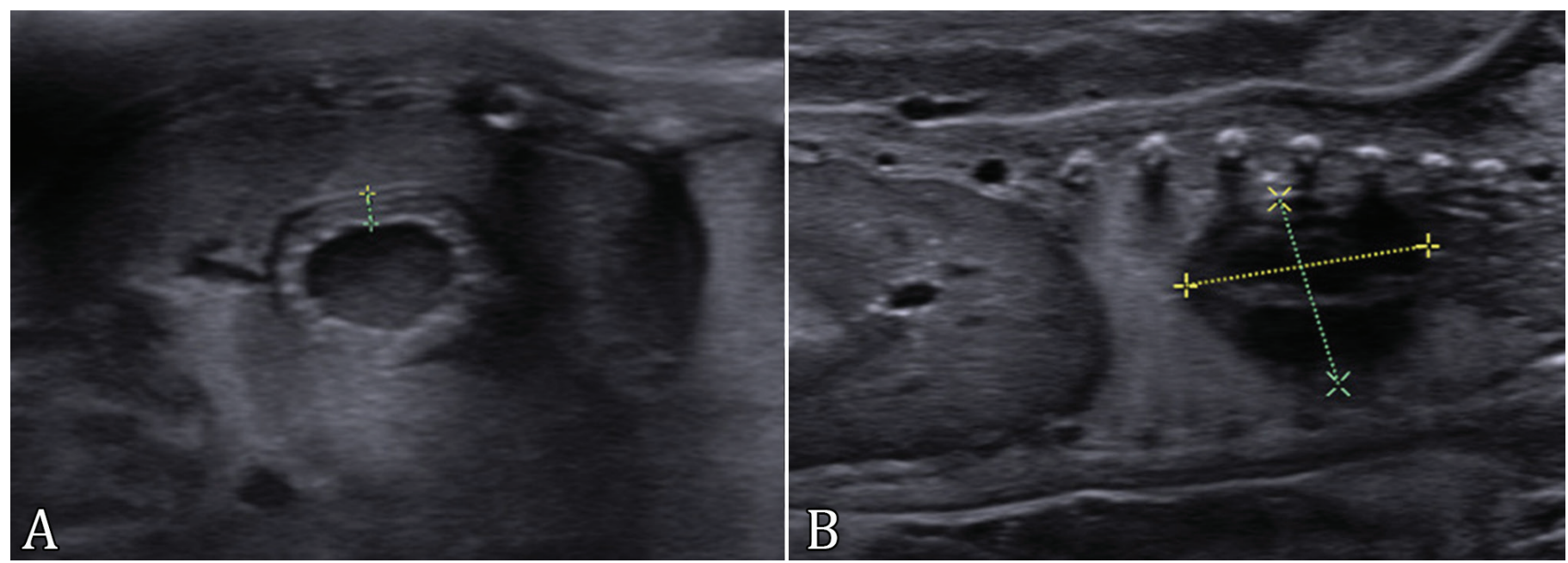

Fig.6. (A) Stomach wall thickness (between cursors) and (B) heart length and height (between cursors). 
(Frusca et al. 2018). Similarly, the length of the femur in brachycephalic bitches in the present study demonstrated excellent predictive power for determination of gestational age $\left(\mathrm{R}^{2}=97 \%\right)$, higher than that reported by Feliciano et al. (2015) (R2=90\%). It is evident that the length of the humerus demonstrates better correlation with gestational age when compared to length of the femur, which corroborates the reports by Camargo et al. (2011). Similar to the observations in humans, the results obtained for bones such as the scapula and radius have also demonstrated excellent correlation with
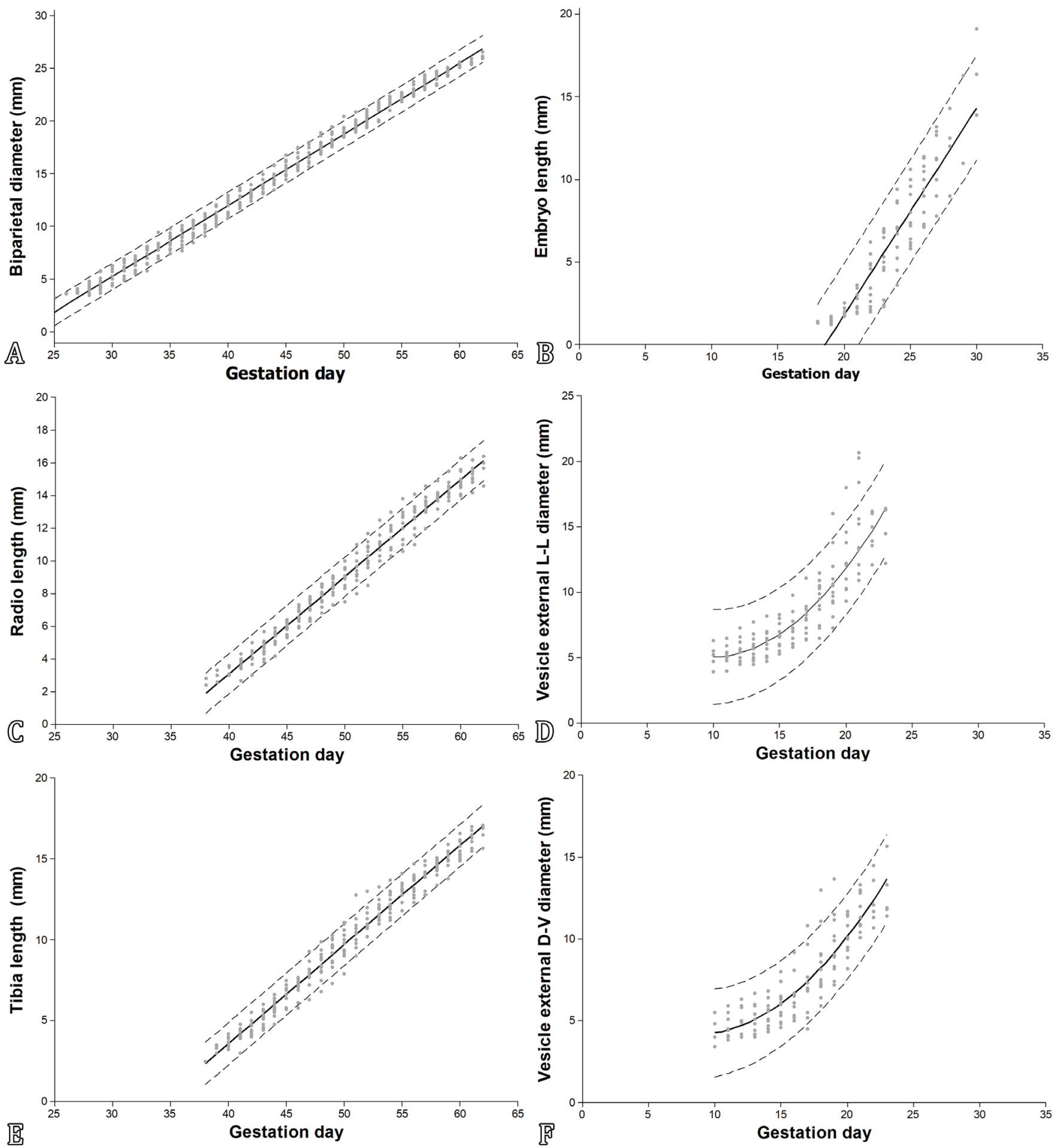

Fig.7. Graphical representation of the echobiometric parameters that presented the best coefficients of determination (R2) to calculate embryonic gestational age (days) (right: EL = embryo length, EDV = external dorsoventral diameter, ELL = external latero-lateral diameter of the embryonic vesicle) and fetal age (left: BPD = biparietal diameter, RAD = radius, TIB = tibia length) in brachycephalic bitches evaluated daily (from day 8 after artificial insemination until the day of delivery) using high-definition ultrasonography. 
gestational age (Arduini \& Giacomello 2009). However, among the echobiometric measurement of bones, the best predictor was length of the tibia $\left(\mathrm{R}^{2}=97.3 \%\right)$, which is not considered in humans as measurement of the length of the femur is easier (Arduini \& Giacomello 2009). Additionally, we believe that this measurement can assist in monitoring bones development, for early detection of congenital diseases and underdeveloped fetuses as reported in humans (Bunduki et al. 2002)

Adrenal biometry analyzed in the present study can provide valuable information to veterinarians, since there are no reports of the identification and/or measurement of this structure in canine fetuses using ultrasonography. This parameter presented good correlation with prediction of gestational age $\left(\mathrm{R}^{2}=89.6 \%\right)$. However, further studies are required to validate this parameter as a predictor of preterm delivery in dogs, as observed in human women, with $87 \%$ specificity. The fetuses of human women who are at risk of preterm birth have larger adrenal gland than normal fetuses (Turan et al. 2011).

This study provides important information that can be used in the ultrasound evaluation of pregnant brachycephalic patients. The limitations of this study were the absence of LH measurements. However, we consider that the results can be applied to animals that have and haven't evaluated LH peak, once many tutors who do not have access to LH peak evaluation, It can be considered an advantage in the clinical application of this study.

Table 1. Results of the regression study of the echobiometric parameters that showed a significant correlation $(\mathrm{P}<0.05)$ with gestational days (GD), predictive formulas and the coefficient of determination for these parameters (R2) in brachycephalic bitches evaluated daily (from day 8 after artificial insemination until the day of delivery) using highdefinition ultrasonography

\begin{tabular}{|c|c|c|c|}
\hline Parameters & GD & $\mathrm{R}^{2}(\%)$ & Predictive formulas \\
\hline BPD & $25-63$ & 99.1 & $\mathrm{GD}=22.4+1.5 \times \mathrm{DBP}$ \\
\hline RAD & $38-63$ & 97.5 & $\mathrm{GD}=35.2+1.6 \times \mathrm{RAD}$ \\
\hline TIB & $38-63$ & 97.3 & $\mathrm{GD}=34.6+1.6 \times \mathrm{TIB}$ \\
\hline $\mathrm{AD}$ & $30-63$ & 97.2 & $\mathrm{GD}=29.8+0.75 \times \mathrm{DA}$ \\
\hline FEM & $30-63$ & 96.6 & $\mathrm{GD}=33.6+1.4 \times \mathrm{FEM}$ \\
\hline HUM & $38-63$ & 96.5 & $\mathrm{GD}=34.5+1.5 \times \mathrm{UME}$ \\
\hline $\mathrm{KH}$ & $31-63$ & 96.0 & $\mathrm{GD}=33.4+2.1 \times \mathrm{AR}$ \\
\hline ESC & $36-63$ & 95.8 & $\mathrm{GD}=34.8+1.6 \times \mathrm{ESC}$ \\
\hline KL & $24-63$ & 95.8 & $\mathrm{GD}=25.5+2.6 \times \mathrm{CR}-0.05 \times \mathrm{CR} 2$ \\
\hline HL & $31-63$ & 93.0 & $\mathrm{GD}=31.5+1.7 \times \mathrm{CC}$ \\
\hline $\mathrm{HH}$ & $31-63$ & 91.5 & $\mathrm{GD}=32.3+1.3 \times \mathrm{AC}$ \\
\hline AGL & $38-63$ & 89.6 & $\mathrm{GD}=32.5+5.8 \times \mathrm{CAD}$ \\
\hline STO & $27-63$ & 86.9 & $\mathrm{GD}=24+22.5 \times \mathrm{EST}$ \\
\hline EL & $17-30$ & 85.7 & $\mathrm{GD}=19.3+0.7 \times \mathrm{CE}$ \\
\hline ELL & $10-23$ & 81.8 & $\mathrm{GD}=2.4+2.3 \times$ LLE $-0.07 \times$ LLE 2 \\
\hline EDV & $10-23$ & 79.8 & $\mathrm{GD}=3.7+2.3 \times$ DVE $-0.07 \times$ DVE2 \\
\hline ILL & $10-23$ & 74.9 & $\mathrm{GD}=9.8+2.7 \times \mathrm{LLI}-0.15 \times$ LLI2 \\
\hline IDV & $10-23$ & 74.0 & $\mathrm{GD}=10+3.4 \times \mathrm{DVI}-0.25 \times \mathrm{DVI} 2$ \\
\hline
\end{tabular}
$\mathrm{BPD}=$ biparietal diameter, $\mathrm{RAD}=$ length of the radius, $\mathrm{TIB}=$ tibial length, $\mathrm{AD}=$ abdominal diameter, $\mathrm{FEM}=$ length of the fêmur, $\mathrm{HUM}=$ length of the humerus, $\mathrm{KH}=$ kidney height, $\mathrm{ESC}=$ length of the scapula, $\mathrm{KL}=$ kidney length, $\mathrm{HL}=$ heart length, $\mathrm{HH}=$ heart height, $\mathrm{AGL}=$ adrenal length, $\mathrm{STO}=$ thickening of the stomach wall, EL = embryo length, ELL = external latero-lateral diameter of the embryonic vesicle, EDV = external dorsoventral diameter of the embryonic vesicle, ILL = internal latero-lateral diameter of the embryonic vesicle, IDV = internal dorsoventral diameter of the embryonic vesicle.

\section{CONCLUSIONS}

All biometric measurements studied using high-definition ultrasonography were predictive value for gestational age estimation in brachycephalic bitches after artificial insemination.

Biparietal diameter may be considered as the best predictor of gestational age in fetuses due to the accuracy of detection and measurement from day 25 until the day of delivery. The length of the radius and tibia are also important measurements during the period from day 35 to delivery. On the other hand, the measurement of the external diameter of the embryonic vesicle and fetal length were the most adequate parameters to calculate gestational age in embryos of brachycephalic bitches.

These results provide an important base for obstetric evaluation of this type of bitches and opens doors for the study of gestational development using high-definition tools.

Acknowledgements.- The present study was supported by "Fundação de Amparo à Pesquisa do Estado de São Paulo" (FAPESP) in the form thematic project (2017/14957-6; 2019/15282-8) and "Conselho Nacional de Desenvolvimento Científico e Tecnológico" (CNPq) in the form of a Doctor's degree scholarship (process number 141098/2016-3) and productivity scholarship (process number 309199/2017-4). The authors also thank Jair Matos and Siemens Healthineers for technical assistance.

Conflict of interest statement.- The authors declare that they have no competing interest.

\section{REFERENCES}

Abi-Nader K., Whitten S.M., Filippi E., Scott R. \& Jauniaux E. 2009. Dichorionic triamniotic triplet pregnancy complicated by Acardius Acormus. Fetal Diagn. Ther. 26(1):45-49. <https://dx.doi.org/10.1159/000236360> <PMid:19816031>

Arduini D. \& Giacomello F. 2009. Fetal biometry, estimation of gestational age, assessment of fetal growth, p.141-155. In: Wladimiroff J.W. \& Eik-Nes S.H. (Eds), Ultrasound in Obstetrics and Gynaecology. Elsevier, New York.

Bonilla-Musoles F., Raga F., Castillo J.C., Bonilla Jr. F., Climen M.T. \& Caballero 0. 2013. High definition real-time ultrasound (HDLive) of embryonic and fetal malformations before week 16. Donald School J. Ultrasound Obstet. Gynecol. 7(1):1-8. <https://dx.doi.org/10.5005/jp-journals-10009-1266>

Brennan S., Watson D., Rudd D., Schneider M. \& Kandasamy Y. 2017. Evaluation of fetal kidney growth using ultrasound: a systematic review. Eur. J. Radiol. 96:55-64. <https://dx.doi.org/10.1016/j.ejrad.2017.09.017> <PMid:29103476>

Bunduki V., Ruano R., Peralta C.F.A., Miguelez J., Carvalho M.B., Yoshizaki C.T. \& Zugaib M. 2002. Rastreamento antenatal da síndrome de down utilizando parâmetros ultra-sonográficos. Revta Bras. Ginecol. Obstetr. 24(9):601-608. <https://dx.doi.org/10.1590/S0100-72032002000900006>

Camargo N.I., Berlim A.T., Magalhães F.J.R., Manso Filho H.C. \& Wischral A. 2011. Fetal biometry in Shih-Tzu female dogs by ultrasound. Med. Vet. 5(1):1-6.

Concannon P.W., McCann J.P. \& Temple M. 1989. Biology and endocrinology of ovulation, pregnancy and parturition in the dog. J. Reprod. Fertil. 39(Supl.):3-25. <PMid:2695640>

David A.L., Abi-Nader K.N., Weisz B., Shaw S.W.S., Themis M., Cook T., Coutelle C., Rodeck C. \& Peebles D.M. 2010. Ultrasonographic development of the fetal sheep stomach and evaluation of early gestation ultrasound-guided in utero intragastric injection. Taiwan. J. Obstet. Gynecol. 49(1):23-29. <https://dx.doi.org/10.1016/S1028-4559(10)60004-6><PMid:20466288>

Dias T., Sairam S. \& Kumarasiri S. 2014. Ultrasound diagnosis of fetal renal 505 abnormalities. Best Pract. Res. Clin. Obstet. Gynaecol. 28(3):403-415. <https://dx.doi.org/10.1016/j.bpobgyn.2014.01.009><PMid:24524801> 
Feliciano M.A.R., Cardilli D.J., Nepomuceno A.C., Crivalero R.M., Silva M.A.M., Coutinho L.N., Oliveira M.E.F. \& Vicente W.R.R. 2014. Echobiometrics kidney and renal artery triplex doppler of canine fetuses. Arq. Bras. Med. Vet. Zootec. 66(2):445-449. <https://dx.doi.org/10.1590/1678-41626120>

Feliciano M.A.R., Maciel G.S., Coutinho L.N., Almeida V.T., Uscategui R.A.R. \& Vicente W.R.R. 2015. Gestational echo biometry in brachycephalic pregnant bitches. Ciênc. Anim. Bras. 16(3):419-427. <https://dx.doi org/10.1590/1089-6891v16i327069>

Feliciano M.A.R., Muzzi L.A.L., Leite C.A.L. \& Junqueira M.A. 2007. Ultrasonografia bidimensional convencional, de alta resolução e tridimensional no acompanhamento da gestação em cadela. Arq. Bras. Med. Vet. Zootec. 59(5):1333-1337.<https://dx.doi.org/10.1590/S0102-09352007000500037>

Feliciano M.A.R., Nepomuceno A.C., Crivalero R.M., Oliveira M.E.F., Coutinho L.N. \& Vicente W.R.R. 2013. Foetal echoencephalography and Doppler ultrasonography of the middle cerebral artery in canine foetuses. J. Small Anim. Pract. 54(3):149-152. <https://dx.doi.org/10.1111/jsap.12038> $<$ PMid:23458645>

Feliciano M.A.R., Vicente W.R.R., Leite C.A.L. \& Muzzi L.A.L. 2008. Novas perspectivas no diagnóstico ultra-sonográfico gestacional em cadelas: revisão de literatura. Clín. Vet. 13:56-60.

Freitas L.A., Mota G.L., Silva H.V.R., Carvalho C.F. \& Silva L.D.M. 2016. Can maternal-fetal hemodynamics influence prenatal development in dogs? Anim. Reprod. Sci. 172:83-93. <https://dx.doi.org/10.1016/j. anireprosci.2016.07.005><PMid:27509872>

Frusca T., Todros T., Lees C. \& Bilardo C.M. 2018. Outcome in early-onset fetal growth restriction is best combining computerized fetal heart rate analysis with ductus venosus Doppler: insights from the Trial of Umbilical and Fetal Flow in Europe. Am. J. Obstet. Gynecol. 218(2S):S783-S789. <https://dx.doi.org/10.1016/j.ajog.2017.12.226><PMid:29422211>

Gil E.M.U., Garcia D.A.A. \& Froes T.R. 2015. In utero development of the fetal intestine: Sonographic evaluation and correlation with gestational age and fetal maturity in dogs. Theriogenology 84(5):681-686. <https://dx.doi.org/10.1016/j.theriogenology.2015.04.030><PMid:26025243>

Gil E.M.U., Garcia D.A.A., Giannico A.T. \& Froes T.R. 2014. Canine fetal heart rate: do accelerations or decelerations predict the parturition day in bitches? Theriogenology 82(7):933-941. <https://dx.doi.org/10.1016/j. theriogenology.2014.04.025><PMid:24888684>

Gil E.M.U., Garcia D.A.A., Giannico A.T. \& Froes T.R. 2018. Early results on canine fetal kidney development: Ultrasonographic evaluation and value in prediction of delivery time. Theriogenology 107:180-187. <https://dx.doi.org/10.1016/j.theriogenology.2017.11.015><PMid:29169145>

Jabin V.C.P., Finardi J.C., Mendes F.C.C., Weiss R.R., Kozicki L.E. \& Moraes R. 2007. Use of ultrasonography exams to determinate the parturition day by Yorkshire canine breed. Arch. Vet. Sci. 12(1):63-79.

Jacomini J.O., Cunha G.N. \& Moreira C.F. 2006. Use of the artificial insemination in Bulldogs bitches. Vet. Not. 12:141-144.

Johnsen S.L., Wilsgaard T., Rasmussen S., Hanson M.A., Gdofrey K.M. \& Kiserud T. 2008. Fetal size in the second trimester is associated with the duration of pregnancy, small fetuses having longer pregnancies. BMC Pregnancy Childbirth 8:1-7. <https://dx.doi.org/10.1186/1471-2393-8-25> <PMid:18627638>

Lopate C. 2008. Estimation of gestational age and assessment of canine fetal maturation using radiology and ultrasonography: a review. Theriogenology 70(3):397-402. <https://dx.doi.org/10.1016/j.theriogenology.2008.05.034> $<$ PMid:18534674>

Mattoon J.S. \& Nyland T.G. 2015. Small Animal Diagnostic Ultrasound. 3rd ed. Elsevier, St Louis.

Miranda S.A. \& Domingues S.F.S. 2010. Conceptus ecobiometry and triplex Doppler ultrasonography of uterine and umbilical arteries for assessment of fetal viability in dogs. Theriogenology 74(4):608-617.<https://dx.doi. org/10.1016/j.theriogenology.2010.03.008><PMid:20494430>

Monteiro C.L.B., Madeira V.L.H. \& Silva L.D.M. 2011. Diagnóstico da gestação em gatas. Revta Bras. Reprod. Anim. 35(4):385-392.

Nawapun K., Phithakwatchara N., Jaingam S., Viboonchart S., Mongkolchat N. \& Wataganara T. 2018. Advanced ultrasound for prenatal interventions. Ultrasonography 37(3):200-210. <https://dx.doi.org/10.14366/usg.18011> <PMid:29852543>

Nepomuceno A.C., Garcia D.A.A. \& Barros F.F.P.C. 2013. Ultrassonografia do sistema reprodutor feminino de pequenos animais, p.41-67. In: Feliciano M.A.R., Oliveira M.E.F. \& Vicente W.R.R. (Eds), Ultrassonografia na Reprodução. MedVet, São Paulo.

Phemister R.D. 1974. Nonneurogenic reproductive failure in the bitch. Vet. Clin. N. Am. 4(3):573-586. <https://dx.doi.org/10.1016/s00910279(74)50060-7><PMid:4604825>

Pieri N.C.G., Souza A.F., Casals J.B., Roballo K.C.S., Ambrósio C.E. \& Martins D.S. 2015. Comparative development of embryonic age by organogenesis in domestic dogs and cats. Reprod. Domest. Anim. 50(4):625-631. <https:// dx.doi.org/10.1111/rda.12539><PMid:25990819>

Pretzer S.D. 2008. Canine embryonic and fetal development: a review. Theriogenology 70(3):300-303. <https://dx.doi.org/10.1016/j. theriogenology.2008.04.029><PMid:18513790>

Sharma L.K., Sarath T., Joseph C., Sridevi P., Arunmozhi N. \& Monica G. 2018. Ultrasonographic diagnosis of fetal resorption in relation to age, parity, body condition and breed in bitches. Int. J. Curr. Microbiol. Appl. Sci. 7(6):161166. <https://dx.doi.org/10.20546/ijcmas.2018.706.019>

Teixeira M.J., Souza D.M.B., Melo K.C.M. \& Wischral A. 2009. Estimativa da data do parto em cadelas rottweiler através da biometria fetal realizada por ultrassonografia. Ciênc. Anim. Bras. 10(3):853-861. <https://dx.doi. org/10.5216/cab.v10i3.1828>

Turan O.M., Turan S., Funai E.F., Buhimschi I.A., Campbell C.H., Bahtiyar O.M., Harman C.R., Copel J.A., Buhimschi C.S. \& Baschat A.A. 2011. Ultrasound measurement of fetal adrenal gland enlargement: an accurate predictor of preterm birth. Am. J. Obstet. Gynecol. 204(4):311.e1-311.e10. <https:// dx.doi.org/10.1016/j.ajog.2010.11.034><PMid:21292230> 